\title{
Credit Rating Changes and Stock Market Reaction in the Kingdom of
} Bahrain

\author{
Marwan M. Abdeldayem ${ }^{1} \&$ Ramzi Nekhili ${ }^{2}$ \\ ${ }^{1}$ Faculty of Commerce, Cairo University, Egypt and Applied Science University, Bahrain \\ ${ }^{2}$ College of Administrative Sciences, Applied Science University, Kingdom of Bahrain \\ Correspondence: Author, College of Administrative Science, Applied Science University, Manama, P. O Box \\ 5055, Kingdom of Bahrain. Tel: 973-3512-1048. E-mail: Marwan.Abdeldayem@asu.edu.bh
}

Received: May 10, 2016

doi:10.5539/ijef.v8n8p23
Accepted: May 27, 2016

URL: http://dx.doi.org/10.5539/ijef.v8n8p23

\begin{abstract}
Between 2014 and 2015, the oil price almost halved. Since then, it has fallen a further 40\%. Consequently, Moody's Investors Service has downgraded Bahrain's long-term issuer rating from Baa3 to Ba1with a negative outlook and placed it on review for further downgrade. In this context, previous literature reaches no agreement about the impact of credit rating changes on stock prices. Some studies indicate that credit rating changes do not affect stock prices, while others conclude they do. Therefore, this study aims to examine whether credit rating change has a significant impact on Bahraini stock prices. We conducted an event study to analyze stock market reaction to such news in the Kingdom of Bahrain. Even though Bahrain has witnessed a series of sovereign downgrades over the past five years, the latest downgrading event in February 17, 2016, has been followed by a credit rating downgrade of its banking sector in March 7, 2016. Hence the choice of the sample period of the event study includes both these downgrading events over the period of study from January 2, 2014 till March 22, 2016. Three sectors were selected from the Bahrain all share index: banks, service and industrial. The findings of the study reveal that sovereign rating downgrade has some mixed pre-announcement and post-announcement effects and credit rating downgrade provides useful information. Overall, the results indicate that downgrades and negative outlook announcements have an adverse impact on long-term equity returns, but little impact on short-term performance.
\end{abstract}

Keywords: credit rating changes, sovereign, stock prices, event study, Bahrain stock market

\section{Introduction}

Little evidence has been recorded on the analysis of information efficiency of ratings in the Gulf countries compared to the U.S. markets. The case of Kingdom of Bahrain is one of them and assessing the impact of rating actions on its market prices may add to the existing empirical literature. This may provide financial markets authorities with insights in utilizing external ratings as a regulatory tool in the Middle East region and Gulf countries.

Credit rating agencies, such as Moody's Investors Service or Standard \& Poor's, play an important role in the financial markets and do typically impact investors' decisions (Gropp \& Richards, 2001; Ferri \& Morone, 2008). They also influence market prices of financial instruments that are available as investment vehicles for investors. Moreover, credit rating agencies display a pro-cyclical behavior in upgrading countries in good times and downgrading in bad times. This may reduce or magnify patterns in stock markets. Oil-exporting sovereigns like the Kingdom of Bahrain has been under a series of downgrading announcements impacting prices and affecting the pool of investors who hold investment grade instruments such as commercial bank stocks. In fact, persistent low oil prices have created a strong fiscal pressure on the government of Bahrain and lowered its capacity in supporting its banking sector when needs pop up. Effectively, such credit profile has been followed by a credit rating downgrade of five major commercial banks in the kingdom.

Standard \& Poor's downgraded Bahrain's sovereign debt by two levels to BB on February 17, 2016, claiming that the collapse in oil prices would aggravate Bahrain's public finances. Later and in March 2016, Moody's Investors Service has announced a downgrade of Bahrain's sovereign rating from Baa3 to Ba1 with a perspective of further downgrade. The key driver for the rating downgrade is the highly negative effect of the slump in oil 
prices, which is expected to last for many years, on Bahrain's government finances, balance of payments and economic performance. Furthermore, Bahrain's foreign currency bond ceiling has gone down from Baa1 to Baa2 and foreign currency deposit ceiling from $\mathrm{Baa} 3$ to $\mathrm{Ba}$. The short-term foreign currency bond ceiling went down from Prime-2 (P-2) to Prime-3 (P-3), as well as the short-term foreign-currency deposit ceiling that went down from P-3 to Not Prime (NP). Bahrain's local currency country risk ceilings were lowered to Baa1 from A3.

This paper investigates the credit rating changes and its effect on stock prices by analyzing specific Bahraini industries, banking, industrial, and service. These industries are selected because of their relative high market capitalization and trading volumes compared with the other existing industries in Bahrain stock market. This focus on specific industries may differentiate this analysis from other event studies conducted on analyzing credit rating changes and their effect on stock prices. It has been noticed that none of the existing companies included in the specific industries under investigation have investment grade bonds. Nevertheless, the banking sector includes five commercial banks having investment grade bonds and most of the events happened around downgrading announcements. Consequently, we analyze the downgrade that took place in the banking sector.

The rest of the paper is organized as follows: Section 2 wraps up a literature review that deals with the relation between credit rating changes and stock prices; Section 3 describes the research methodology; Section 4 presents the empirical analysis and test results of the relation between credit rating changes and stock prices; Section 5 provides summary and concluding remarks.

\section{Literature Review}

Numerous studies in the finance literature have investigated the impact of credit rating changes on capital markets in developed countries particularly in the U.S. Empirically, some studies have examined this impact on the price or return of bonds such as Katz (1974), Ederington et al. (1987), Goh and Ederington (1999). Another set of studies measured this impact on stocks, for example, Pinches and Singelton (1978), Holthausen and Leftwich (1986), Followill and Martell (1997), Jorion et al. (2005), Jorion and Zhang (2007). More recently some studies investigated the credit default swaps, such as Micu et al. (2004), and Cathcort et al. (2010). Moreover, few studies have also investigated the European market such as Gropp and Richards (2001), Cesare (2006) and single countries, for example, in UK, the study of Barron et al. (1997) and Batchelor and Manzoni (2006), in Germany, the study of Steiner and Heinke (2001), and in Spain, the study of Pilar and Dolores (2014). Reviewing all these studies clearly shows the diversity of the results of the responses to credit rating changes.

For example, Weinstein (1977) studies the behavior of corporate bond prices before and after the announcement of a credit rating change. The study indicates that the market should not expect that bond rating changes detect new information. In addition, 18 to 7 months before the announcement of the rating change, an evidence of price change was found. Contrarily, and 6 months prior to the announcement of a rating change, no price change was found. Nevertheless, the study shows little evidence price change 6 months post the announcement. These results are different for Wakeman (1978) who finds no price response using weekly bond returns and monthly stock returns.

Other studies reveal that bond rating downgrades do affect the stock price while upgrades do not. Griffin and Sanvicente (1982) determine that in most cases bond downgrades significantly induce a negative stock price reaction, while upgrades do not. They conclude that their results are in line with the logic that rating downgrades notify new information to the stock market. However, they do not set aside the fact that downgraded companies are already doing worse than normal and this paradigm just carries on after the downgrade.

Moreover, Holthausen and Leftwich (1986) report the existence of a link between credit rating downgrades and negative abnormal stock returns, while no link is found for upgrades. Using daily stock returns, and after controlling the simultaneous issues of news, they found negative significant abnormal returns during a 2-day event window. Similarly, Hand et al. (1992) report in their study on the US market that rating downgrades conveys new information to investors, while upgrades have no impact as news are already absorbed in the prices.

In addition, Goh and Ederington (1993) conclude similar findings, however they explain rating downgrades in more details, grouping downgrades into two types: those because of decay in the company's financial outlook and those because of an increase in leverage. Companies that are downgraded because of deterioration in company's financial prospects have a negative equity market reaction, whilst those because of increased leverage do not.

In a more recent study, Goh and Ederington (1999), examine the variability of the reaction to downgrade announcements in function of the implications for cash flows and the extent of surprise. The findings reveal a significant negative cumulative abnormal return (CAR) in a two-day event window around both downgrades and 
upgrades announcement. The study relates downgrades with the existence of prior negative public information, while upgrades exist only because of public information.

Dichev and Piotroski (2001) examine the post announcement reaction by studying the price effect over a three year horizon. They divided downgrades and upgrades into two subsamples according to whether they belong to holding or subsidiaries. The findings were only significant for the downgrades. The post announcement impact lasts at least one year and is more evident for holdings, small companies and lower rated enterprises.

Jorion and Zhang (2007) investigate also the impact of rating changes on stock returns within a two-year event window. The results show that downgraded companies have a significant negative CAR, while upgraded companies display insignificant cumulative abnormal returns. However, and for upgrades of speculative grade issues, the results show a positive and significant average CAR but of a smaller magnitude than the downgrade effect.

Minardi (2008) claims that the information of credit rating is efficient in predicting Brazilian companies' default probabilities. Bone and Ribeiro (2009) examine the impact of rating changes in the Brazilian stock market over the period from 1995 to 2007 . They check if rating change announcements affect systematic risk. The study uses the Chow stability test and shows no evidence of structural breaks pre or post the change. Further, Cisneros et al. (2012) report that credit rating agencies' reports are important and become of good quality since the improvements in the regulatory environment in Peru, Chile and Colombia.

To conclude, early studies on the impact of rating changes, using either daily or monthly data for the U.S. bond market, found either mixed evidence (such as Pinches \& Singleton, 1978) or no effect at all (Weinstein, 1977; Wakeman, 1978). Their findings mainly conclude that most of the rating actions happen after the occurrence of publicly known events. Recent studies adopt a methodology that breaks down the rating actions into different subgroups based on whether they were foregone by a credit watch in the same direction or by inaccurate information. Hand et al. (1992), among the others, find out that only negative watches and downgrades significantly impact stock and bond prices. Therefore, this research effort may shed some light into the relationship between credit rating changes and stock market reaction in the Gulf area, particularly in the Kingdom of Bahrain. Hence, this study would motivate researchers to examine this relationship perhaps in some other Gulf countries such as Saudi Arabia, UAE, Kuwait, Qatar or Oman.

\section{Methodology}

This paper adopts an event study approach as proposed by Campbell, Lo, and Mackinlay (1997). Such approach is merely used by finance and economics scholars to determine the impact of an event on a particular variable of interest. This paper examines the event of a ratings downgrade for sovereign bond and a particular company's bond, and its impact on the stock price. However, before carrying such examination, it is important to determine how we expected the price to act if there was no event. There are a few alternatives for determining the expected return, and while some studies use an average of the returns over some period of time prior to the event, in this paper we use a market model, allowing us to make a more accurate prediction of expected return.

We use an event window equal to twenty days before $(-20)$ and twenty days after $(+20)$ the date of a rating change announcement (0). According to Ford, Jackson and Skinner (2010) and Freitas and Minardi (2013) the choice of the window should neither be too long nor too small such that it does not encompass other events and fails to capture abnormality in prices. Also, the literature does not seem to have a consensus in defining the event window. Dichev and Piotroski (2001) check different event windows: 0 (date of the announcement) to 3 months, to 6 months, to 1 year, to 2 years and to 3 years after the announcement. Jorion and Zhang (2007) checked the event window of 1 year before and after the announcement. Further, they tested different windows ranging from one to fifty days before and after an event.

To perform the event study, we first calculate the return on each asset $i$ by equation (1), where $\ln$ is the natural logarithm, $P_{i, t}$ is the price of asset $i$ on day $t$ and $P_{i, t-1}$ is the price of asset $i$ on day $t-1$.

$$
R_{i, t}=\ln \left(P_{i, t} / P_{i, t-1}\right)
$$

We then estimate the returns over an estimation window that does not overlap with the event window and using the market model, which reads:

$$
R_{i, t}=\alpha_{i}+\beta_{i} R_{m, t}+\varepsilon_{i, t}
$$

Given the market model parameter estimates, we can measure the abnormal returns by equation (3), where $R_{i, t}^{*}$ and $R_{m, t}^{*}$ are the event-window returns of asset $i$ on date $t$ and the event-window market returns, respectively, 
as follows:

$$
A R_{i, t}=R_{i, t}^{*}-\hat{\alpha}_{i}-\hat{\beta}_{i} R_{m, t}^{*}
$$

To draw overall inferences for the credit downgrading event, we aggregate the abnormal returns through time by calculating the cumulative abnormal returns over the entire event window. Taking $\tau_{l}$ and $\tau_{2}$ as two consecutive dates within the event window, we define the cumulative abnormal return for asset $i$ in the following equation:

$$
\operatorname{CAR}_{i}\left(\tau_{1}, \tau_{2}\right)=\sum_{t=\tau_{1}}^{\tau_{2}} A R_{i, t}
$$

We define the null and alternative hypotheses to determine whether the calculated CAR is significant as follows:

$\mathrm{H}_{0}$ : No abnormal return is observed in Bahraini industries' stock prices around the credit rating downgrade

$\mathrm{H}_{1}$ : An abnormal return is observed in Bahraini companies' stock prices around the credit rating downgrade.

We can now construct a test of $\mathrm{H}_{0}$ for asset $i$ to assess the significance of the abnormal returns using the standardized abnormal return in the following t-statistic as in Dodd (1980),

$$
t-\text { stat }=\frac{A R_{i, t}}{\sigma_{i}}
$$

with

$$
\sigma_{i}=\sqrt{\frac{1}{N} \sum_{T=T_{1}}^{T_{2}}\left(A R_{i, T}-A \bar{R}_{i}\right)^{2}}
$$

and where $N$ is the number of observations of the event window $\left(T_{1}, \ldots, 0, \ldots, T_{2}\right)$, and $A \bar{R}_{i}$ is the average event-window abnormal returns.

\section{Analysis and Empirical Findings}

Even though Bahrain has witnessed a series of sovereign downgrades over the past five years, the latest downgrading event in February 17, 2016, has been followed by a credit rating downgrade of its banking sector in March 7, 2016. Hence the choice of the sample period of the event study includes both these downgrading events. Additionally, the selection criteria for the inclusion of a given sector in the event study are based on market capitalization and industry representation. The Bahrain all share index has 45 listed companies and are spread in six sectors. As such, the sectors selected are banks, service, and industrial with a respective market capitalization of $47 \%, 15 \%$, and $14.7 \%$ from a total market capitalization of $\$ 17.5$ billion. Other sectors like investment, hotel and tourism, and insurance not only have the least industry representation but also displayed the lowest trading volumes over the period of study from January 2, 2014 till March 22, 2016. The source of the data of credit rating changes is Standard and Poor's and Moody's Investor Services, the two largest and oldest providers of ratings to the market, and the source of the data is GulfBase data provider. The main data consists of indices representing Bahrain stock market and its chosen sectors. The construction of these indices is price weighted and are available on a daily basis. Additionally, we select the sample based on the following criteria:

- Being a publicly traded company with stocks held by the major stock indexes in the kingdom of Bahrain as of 22/3/2016.

- Having experienced changes in issuer ratings or foreign currency long-term ratings by Moody's or S\&P's between 02/01/2014 and 22/3/2016.

- If a listed company possesses more than one class of stock, we consider the class that has the highest average volume traded between 02/01/2014 and 22/3/2016

- We do not consider rating changes of companies whose stocks were not traded on dates close to the announcement.

Table 1 provides a descriptive statistic summary of the return series of the market and the three sectors under study. The average return is positive for the bank and service sector and negative for the market and the industrial sector. However, they are small compared to their respective volatilities. Despite the low volatility of Bahrain stock market $(0.46 \%)$, the industrial sector has a higher volatility than the other sectors, which could be explained by the fact that Bahrain stock market is more connected to major stock markets in the world than its counterparts in the Gulf region. The distributions of the market and sector returns seem to be non-normal with a negative skewness and excess kurtosis showing fat tails, which is consistent with most emerging markets. 
Table 1. Descriptive statistics for stock returns

\begin{tabular}{lcccc}
\hline & Market & Bank & Service & Industrial \\
\hline Mean & -0.014 & 0.020 & 0.022 & -0.011 \\
Median & -0.016 & 0.021 & 0.000 & 0.000 \\
Standard Deviation & 0.460 & 0.962 & 0.804 & 2.375 \\
Variance & 0.212 & 0.925 & 0.646 & 5.640 \\
Kurtosis & 3.941 & 144.728 & 28.252 & 294.154 \\
Skewness & -0.341 & -8.515 & -1.892 & -14.404 \\
Minimum & -2.842 & -16.097 & -8.219 & -47.486 \\
Maximum & 1.537 & 3.685 & 4.283 & 10.032 \\
\hline
\end{tabular}

The methodology described in the previous section uses the market model as the normal performance return model. The market model parameters are based upon daily return observations beginning 501 days through to 41 days before the sovereign rating change. The event period ranges from 20 days before to 20 days after the rating change. Table 2 summarizes the market model parameter estimates.

Table 2. Market model parameter estimates

\begin{tabular}{cccc}
\hline Coefficient & Bank Sector & Service Sector & Industrial Sector \\
\hline $\boldsymbol{\alpha}$ & 0.017 & 0.038 & -0.004 \\
$\boldsymbol{\beta}$ & $0.182^{*}$ & $0.342^{*}$ & $0.452^{*}$ \\
$\boldsymbol{R}^{2}$ & 0.007 & 0.036 & 0.007 \\
\hline
\end{tabular}

* Denotes 5\% significance level.

On the premise that the literature has revealed that sovereign rating downgrade has some impact on stock market returns, the results displayed in Table 3 show some mixed pre-announcement and post-announcement effects. On the announcement day (day zero), the abnormal return for the bank sector is $-0.066 \%$ and for both the service and industrial sector is $-0.293 \%$ and $-0.368 \%$ respectively, with no significant impact as the t-statistics accept the null hypothesis that the downgrading event has no impact. Focusing on the pre-announcement date, we observe an anticipation of the sovereign downgrade for the bank and industrial sectors only. There is a statistically significant reaction for the bank sector on day -16 with an abnormal return of $-1.158 \%$, and on day -8 and -7 for the industrial sector with respectively $2.587 \%$ and $-2.930 \%$. On the post-announcement date, we observe a significant effect on day 5 and 6 for the industrial sector with significant negative abnormal returns. Whereas, for the bank and service sector, it takes longer times to absorb the sovereign credit rating downgrade, respectively on day 16 and 18 for banks and day 19 for service. This would suggest that investors in the banking sector could earn significant positive returns sixteen days after the announcement as a possible overreaction but then realizing the negative outlook of the economy two days later. Investors in the industrial sector may have realized the negative outlook and have absorbed the announcement at an earlier time than with investors in the service sector. Nevertheless, the significant negative abnormal returns associated with the negative news of credit rating are in line with previous empirical studies. Overall, and within an interval of 5 days, the market seems to anticipate the information provided by the rating agencies as there are no significant abnormal returns whether earned by investing in the bank sector, the service or industrial sector.

In order to provide further insight to the results, we present the results of the effect of the credit rating downgrade of four out of the seven banks that constitute the bank sector portfolio, which took place on March 7 , 2016, on all three sectors. The same methodology has been applied for this downgrading event and where the market model parameters are re-estimated based upon daily return observations beginning 511 days through to 21 days before the credit rating change. We observed no change in the parameter estimates carried out previously. The event period ranges from 10 days before to 10 days after the rating change. Table 4 presents the abnormal returns as well as the cumulative abnormal returns for the three sectors under study. The results are consistent with the empirical literature on the information content of credit rating change. There is supporting evidence that credit rating downgrade provides useful information. In fact, there is a significant negative reaction in both the bank sector and the industrial sector four days after the announcement. Whereas there is a delay of 8 to 9 days for the service sector. 
Table 3. Cumulative abnormal return around sovereign rating downgrade

\begin{tabular}{|c|c|c|c|c|c|c|c|c|c|}
\hline \multirow[b]{2}{*}{ Event Day } & \multicolumn{3}{|c|}{ Bank Sector } & \multicolumn{3}{|c|}{ Service Sector } & \multicolumn{3}{|c|}{ Industrial Sector } \\
\hline & $\mathbf{A R}$ & CAR & T Stats & $\mathbf{A R}$ & CAR & T Stats & $\mathbf{A R}$ & CAR & T Stats \\
\hline-20 & -0.126 & -0.126 & -0.237 & 0.195 & 0.195 & 0.195 & -0.101 & -0.101 & -0.095 \\
\hline-19 & 0.316 & 0.191 & 0.596 & -0.420 & -0.225 & -0.419 & -0.085 & -0.186 & -0.080 \\
\hline-18 & -0.302 & -0.111 & -0.568 & 0.056 & -0.168 & 0.056 & 0.416 & 0.229 & 0.390 \\
\hline-17 & -0.476 & -0.587 & -0.897 & -0.637 & -0.805 & -0.636 & 0.304 & 0.533 & 0.285 \\
\hline-16 & -1.158 & -1.745 & $-2.181 *$ & 0.553 & -0.253 & 0.551 & 0.596 & 1.129 & 0.559 \\
\hline-15 & 0.914 & -0.831 & 1.723 & 0.112 & -0.140 & 0.112 & 0.038 & 1.167 & 0.035 \\
\hline-14 & 0.113 & -0.717 & 0.213 & -0.281 & -0.421 & -0.280 & 0.329 & 1.496 & 0.308 \\
\hline-13 & -0.990 & -1.707 & -1.865 & -0.198 & -0.619 & -0.197 & -0.206 & 1.289 & -0.193 \\
\hline-12 & 0.829 & -0.878 & 1.561 & -0.109 & -0.729 & -0.109 & 0.514 & 1.803 & 0.482 \\
\hline-11 & 0.472 & -0.406 & 0.889 & 0.122 & -0.606 & 0.122 & 1.573 & 3.377 & 1.475 \\
\hline-10 & 0.375 & -0.032 & 0.706 & 0.238 & -0.368 & 0.238 & -1.903 & 1.473 & -1.784 \\
\hline-9 & -0.352 & -0.384 & -0.663 & -0.024 & -0.392 & -0.024 & 1.687 & 3.160 & 1.582 \\
\hline-8 & 0.247 & -0.137 & 0.465 & -0.553 & -0.945 & -0.552 & 2.587 & 5.747 & $2.425^{*}$ \\
\hline-7 & 0.152 & 0.015 & 0.286 & 0.556 & -0.389 & 0.554 & -2.930 & 2.817 & $-2.747^{*}$ \\
\hline-6 & 0.564 & 0.579 & 1.063 & -0.287 & -0.676 & -0.286 & -0.075 & 2.742 & -0.070 \\
\hline-5 & -0.004 & 0.575 & -0.008 & -0.077 & -0.752 & -0.076 & -0.046 & 2.696 & -0.043 \\
\hline-4 & -0.126 & 0.449 & -0.237 & 0.672 & -0.081 & 0.670 & -1.154 & 1.542 & -1.082 \\
\hline-3 & 0.070 & 0.520 & 0.133 & 1.522 & 1.441 & 1.519 & -0.053 & 1.489 & -0.050 \\
\hline-2 & -0.462 & 0.058 & -0.871 & 0.056 & 1.498 & 0.056 & 0.000 & 1.488 & 0.000 \\
\hline-1 & 0.738 & 0.796 & 1.391 & -0.384 & 1.114 & -0.383 & 0.227 & 1.716 & 0.213 \\
\hline 0 & -0.066 & 0.730 & -0.125 & -0.293 & 0.821 & -0.293 & -0.368 & 1.348 & -0.345 \\
\hline 1 & -0.338 & 0.391 & -0.638 & -0.070 & 0.751 & -0.070 & -0.262 & 1.086 & -0.246 \\
\hline 2 & 0.078 & 0.469 & 0.146 & 1.407 & 2.158 & 1.403 & -0.204 & 0.882 & -0.191 \\
\hline 3 & 0.171 & 0.640 & 0.323 & 0.031 & 2.189 & 0.031 & -1.698 & -0.816 & -1.591 \\
\hline 4 & 0.434 & 1.074 & 0.817 & -0.054 & 2.135 & -0.054 & -0.043 & -0.859 & -0.040 \\
\hline 5 & -0.133 & 0.941 & -0.250 & -0.356 & 1.779 & -0.355 & -2.070 & -2.929 & $-1.940 *$ \\
\hline 6 & -0.216 & 0.725 & -0.407 & -0.157 & 1.623 & -0.156 & 2.614 & -0.314 & $2.451 *$ \\
\hline 7 & 0.041 & 0.767 & 0.078 & -0.091 & 1.532 & -0.091 & 0.019 & -0.295 & 0.018 \\
\hline 8 & -0.125 & 0.642 & -0.235 & -0.168 & 1.364 & -0.167 & -0.166 & -0.462 & -0.156 \\
\hline 9 & -0.135 & 0.507 & -0.255 & -0.117 & 1.247 & -0.117 & -0.832 & -1.294 & -0.780 \\
\hline 10 & -0.754 & -0.248 & -1.421 & 0.212 & 1.459 & 0.212 & 0.189 & -1.105 & 0.177 \\
\hline 11 & 0.670 & 0.422 & 1.261 & 0.236 & 1.695 & 0.236 & -0.645 & -1.750 & -0.604 \\
\hline 12 & -0.122 & 0.300 & -0.230 & -0.054 & 1.641 & -0.054 & -0.074 & -1.824 & -0.069 \\
\hline 13 & 0.546 & 0.846 & 1.029 & -0.070 & 1.571 & -0.070 & 0.099 & -1.724 & 0.093 \\
\hline 14 & 0.014 & 0.860 & 0.026 & -0.296 & 1.276 & -0.295 & 1.146 & -0.578 & 1.074 \\
\hline 15 & -0.432 & 0.428 & -0.814 & -0.247 & 1.028 & -0.247 & -0.531 & -1.109 & -0.498 \\
\hline 16 & 1.143 & 1.571 & $2.153 *$ & -0.310 & 0.718 & -0.309 & -0.012 & -1.121 & -0.012 \\
\hline 17 & -0.943 & 0.629 & -1.776 & 0.488 & 1.206 & 0.487 & -0.898 & -2.019 & -0.842 \\
\hline 18 & -1.058 & -0.429 & $-1.992 *$ & -0.679 & 0.527 & -0.678 & -0.230 & -2.249 & -0.215 \\
\hline 19 & -0.185 & -0.614 & -0.349 & -5.443 & -4.916 & $-5.430 *$ & 0.987 & -1.262 & 0.925 \\
\hline 20 & -0.133 & -0.748 & -0.251 & 1.652 & -3.264 & 1.648 & 0.131 & -1.131 & 0.122 \\
\hline
\end{tabular}

* Denotes $5 \%$ significance. 
Table 4. Cumulative abnormal return around banks credit rating downgrade

\begin{tabular}{|c|c|c|c|c|c|c|c|c|c|}
\hline \multirow[b]{2}{*}{ Event Day } & \multicolumn{3}{|c|}{ Bank Sector } & \multicolumn{3}{|c|}{ Service Sector } & \multicolumn{3}{|c|}{ Industrial Sector } \\
\hline & $\mathbf{A R}$ & CAR & T Stats & $\mathbf{A R}$ & CAR & T Stats & $\mathbf{A R}$ & CAR & T Stats \\
\hline-10 & -0.571 & -0.126 & -0.544 & 0.592 & 0.592 & 0.864 & -0.476 & -0.476 & -1.041 \\
\hline-9 & 0.046 & -0.080 & 0.043 & -0.607 & -0.015 & -0.886 & -0.469 & -0.945 & -1.025 \\
\hline-8 & 0.078 & -0.002 & 0.074 & -0.145 & -0.160 & -0.211 & -0.492 & -1.437 & -1.075 \\
\hline-7 & -0.447 & -0.449 & -0.426 & 0.466 & 0.306 & 0.679 & 0.266 & -1.171 & 0.581 \\
\hline-6 & -0.388 & -0.838 & -0.370 & -0.408 & -0.102 & -0.596 & -0.392 & -1.563 & -0.857 \\
\hline-5 & 0.256 & -0.582 & 0.244 & -0.534 & -0.637 & -0.779 & 0.160 & -1.403 & 0.351 \\
\hline-4 & 0.213 & -0.369 & 0.203 & 0.182 & -0.455 & 0.265 & -0.501 & -1.903 & -1.094 \\
\hline-3 & 0.012 & -0.357 & 0.011 & -0.949 & -1.404 & -1.384 & -0.071 & -1.974 & -0.155 \\
\hline-2 & -0.063 & -0.420 & -0.060 & 0.203 & -1.200 & 0.296 & 0.737 & -1.237 & 1.610 \\
\hline-1 & -0.452 & -0.872 & -0.431 & 0.125 & -1.075 & 0.183 & -0.026 & -1.263 & -0.057 \\
\hline 0 & 0.626 & -0.247 & 0.596 & -0.890 & -1.965 & -1.298 & 0.507 & -0.757 & 1.107 \\
\hline 1 & -0.953 & -1.199 & -0.907 & 0.232 & -1.732 & 0.339 & -0.830 & -1.587 & -1.815 \\
\hline 2 & -0.622 & -1.821 & -0.593 & -0.402 & -2.135 & -0.587 & 0.337 & -1.250 & 0.736 \\
\hline 3 & -0.104 & -1.925 & -0.099 & -0.311 & -2.445 & -0.453 & 0.005 & -1.246 & 0.010 \\
\hline 4 & 3.207 & 1.282 & $3.055^{*}$ & 1.152 & -1.293 & 1.681 & 0.915 & -0.330 & $2.000 *$ \\
\hline 5 & 0.433 & 1.715 & 0.413 & -0.520 & -1.813 & -0.758 & 0.024 & -0.306 & 0.053 \\
\hline 6 & 0.401 & 2.117 & 0.382 & -0.118 & -1.931 & -0.173 & 0.607 & 0.301 & 1.327 \\
\hline 7 & -2.308 & -0.191 & $-2.198 *$ & 0.142 & -1.789 & 0.207 & -0.120 & 0.180 & -0.263 \\
\hline 8 & 1.885 & 1.694 & 1.796 & -1.590 & -3.379 & $-2.320 *$ & -0.138 & 0.042 & -0.302 \\
\hline 9 & -0.393 & 1.300 & -0.375 & -1.822 & -5.201 & $-2.657^{*}$ & -0.245 & -0.203 & -0.535 \\
\hline 10 & 0.878 & 2.178 & 0.836 & 0.142 & -5.058 & 0.208 & -0.547 & -0.750 & -1.196 \\
\hline
\end{tabular}

* Denotes 5\% significance level.

\section{Conclusions}

This study's main conclusion is that an emerging market such as of Bahrain could be seen as forward looking. Knowing that the oil price slump has triggered a series of fiscal pressures on the government, the sovereign downgrading has been expected by market participants and all of the anticipated market consequences of the downgrade are gradually factored into market prices over time, before a downgrade actually happens. Therefore, once the sovereign downgrade is announced, the market movements in the three sectors at the time are not significant. After the announcement, a much delayed significant reaction is witnessed in all three sectors. Such delay however was shorter when a credit rating downgrade is announced for the banking sector. In fact, learning that there is less willingness by the government of Bahrain to support its banks and a weakening of the bank operating conditions, investors in the bank sector and in the industrial sector seemed to be synchronized in displaying a negative reaction. Investors in the service sector seemed to react negatively days later. In a nutshell, this may suggest that downgrades and negative watches adversely impact long-term equity returns, and to a less extent short-term performance.

This study however presents some limitations as it is mainly limited to its small sample size. A larger sample, perhaps from different Gulf countries, with a greater number of observations would have allowed the results to give general insights. Another possible improvement would be in interviewing some policy makers, investors and professionals from the Kingdom of Bahrain (Abdeldayem, 2015). Personal interviews could elicit greater information regarding stock market reaction to credit rating changes in Bahrain. This method could have added important qualitative data and greater insight into the policy makers and investors' thoughts and opinions, so that better understanding and interpretation of the relation between credit rating changes and stock market reaction in the Kingdom of Bahrain would have achieved.

Although the relation between credit rating changes and stock market reaction has been established in the finance literature, to the authors' knowledge, this paper is the first of its kind to examine this issue in the Middle East and particularly in the Kingdom of Bahrain. The findings of this study are confined to one country in the Gulf area, i.e. the Kingdom of Bahrain, and this may limit the generalizability of its results. Hence, future research may conduct a comparative study or cross countries study perhaps in some other Gulf countries such as Saudi Arabia, UAE, Kuwait, Qatar or Oman, especially for examining the relationship between credit rating changes and stock market reaction. Moreover, the assessment of the price impact of rating actions for a particular 
Gulf country, such as Bahrain, may serve for sensitivity checking of earlier research mainly based on U.S. data. Furthermore, it may provide insights for financial markets authorities involved in the evaluation of the usage of the external ratings as a regulatory tool in the Middle East region and Gulf countries.

\section{References}

Abdeldayem, M. M. (2015). Examining the Relationship between Agency Costs and Stock Mispricing: Evidence from the Bahrain Stock Exchange. International Journal of Economics, Commerce and Management, 3(4), 1-35. Retrieved from http://ijecm.co.uk/wp-content/uploads/2015/04/342.pdf

Barron, M., Clare, A., \& Thomas, S. (1997). The effect of bond rating changes and new ratings on UK stock

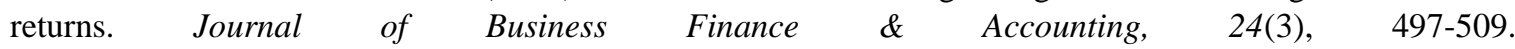
http://dx.doi.org/10.1111/1468-5957.00117

Batchelor, R., \& Manzoni, K. (2006). The dynamics of bond yield spread around rating revisions dates. The Journal of Financial Research, 24(3), 405-420. http://dx.doi.org/10.1111/j.1475-6803.2006.00186.x

Bone, R. B., \& Ribeiro, E. P. (2009). Conteúdo informacional dos ratings corporativos de empresasbrasileiras, 1995-2007. Proceedings of the Brazilian Finance Meeting. São Leopoldo, Brazil, No. (9). http://dx.doi.org/10.11606/t.12.2006.tde-10042007-123346

Campbell, J. Y., Lo, A. W., \& Mackinlay, A. C. (1997). The econometrics of financial markets. New Jersey, EUA: Princeton University Press. http://dx.doi.org/10.1007/bf02925377

Cathcart, L., El-Jahel, L., \& Evans, L. (2010). The correlation structure of the CDS market: An empirical investigation. Unpublished manuscript. http://dx.doi.org/10.2139/ssrn.1571485

Cesare, A. (2006). Do market based indicators anticipate rating agencies? Evidence for international banks. Economic Notes by Banca Monte deiPaschi di Siena SPA, 35(1), 121-150. http://dx.doi.org/10.1111/j.0391-5026.2006.00161.x

Cisneros, D., Lizarzaburu, E. R., \& Salguero, J. Q. (2012). Credit information in emergingmarkets: The rating agencies and credit risk reports, Peruvian experience. International Journal of Business \& Management, 7(24), 35-43. http://dx.doi.org/10.5539/ijbm.v7n24p35

Dichev, I. D., \& Piotroski, J. D. (2001). The Long-Run Stock Returns Following Bond Ratings Changes. The Journal of Finance, 56(1), 173-203. http://dx.doi.org/10.1111/0022-1082.00322

Dodd, P. (1980). Merger proposals, management discretion and stockholders wealth. Journal of Financial Economics, 8, 105-137. http://dx.doi.org/10.1016/0304-405x(80)90014-8

Ederington, L., Yawitz, J., \& Roberts, B. (1987). The informational content of bond ratings. The Journal of Financial Research, 10(3), 211-226. http://dx.doi.org/10.1111/j.1475-6803.1987.tb00492.x

Fama, E. (1970). Efficient capital markets: A review of theory and empirical work. The Journal of Finance, (25), 383-417. http://dx.doi.org/10.2307/2325486

Feng, D., Gourieroux, C., \& Jasiak, J. (2008). The ordered qualitative model for rating transitions. Journal of Empirical Finance, (15), 111-130. http://dx.doi.org/10.1016/j.jempfin.2006.12.003

Ferri, G., \& Morone, A. (2008). The effect of rating agencies on herd behavior. Southern Europe Research in Economics Studies Working Paper No. (22). http://dx.doi.org/10.1007/s11403-013-0114-0

Followill, R., \& Martell, T. (1997). Bond review and rating change announcements: An examination of informational value and market efficiency. The Journal of Economics and Finance, 21(2), 75-82. http://dx.doi.org/10.1007/bf02920766

Ford, G. S., Jackson, J. D., \& Skinner, S. J. (2010). HAC standard errors and the event study methodology: A cautionary note. Applied Economics Letters, July 2010. http://dx.doi.org/10.1080/17446540902817601

Freitas, A. D. N., \& Minardi, A. M. F. (2013). The impact of credit rating changes in Latin American stock markets. BAR, Braz. Adm. Review, 10(4), Rio de Janeiro Oct./Dec. 2013. http://dx.doi.org/10.1590/s1807-76922013000400005

Goh, J. C., \& Ederington, L. H. (1993). Is a Bond Rating Downgrade Bad News, Good News, or No News for Stockholders? Journal of Finance, (48), 2001-2008. http://dx.doi.org/10.1111/j.1540-6261.1993.tb05139.x

Goh, J., \& Ederington, L. (1999). Cross sectional variation in the stock market reaction to bond rating changes. The Quarterly Review of Economics and Finance, 39(1), 101-112. http://dx.doi.org/10.1016/s1062-9769(99)80006-4 
Gompers, P., Ishii, J., \& Metrick, A. (2003). Corporate governance and equity prices. Quarterly Journal of Economics, 118(1), 107-155. http://dx.doi.org/10.1162/00335530360535162

Gonzales, F., Haas, F., Johannes, R., Persson, M., Toledo, L., Violi, R., Zins, C., \& Wieland, M. (2004). Market dynamics associated with credit ratings: A literature review. Banque de France Financial Stability Review, 4, 53-76. http://dx.doi.org/10.2307/2599542

Gopalan, R., Song, F., \& Yerramilli, V. (2010). Do credit rating agencies underestimates liquidity risk? Working Paper Washington University, Pennsylvania State University, and Indiana University. http://dx.doi.org/10.5195/lawreview.2009.148

Griffin, P. A., \& Sanvicente, A. Z. (1982). Common Stock Returns and Rating Changes: A Methodological Comparison. The Journal of Finance, (37), 103-119. http://dx.doi.org/10.2307/2327120

Gropp, R., \& Richards, A. (2001). Rating agency actions and pricing of debt equity of European banks: What can we infer about private sector monitoring of bank soundness? Economic Notes by Banca Monte deiPaschi di Siena SPA, 30(3), 373-398. http://dx.doi.org/10.1111/1468-0300.00064

Hand, J. R. M., Holthausen, R. W., \& Leftwich, R. W. (1992). The Effect of Bond Rating Agency Announcements on Bond and Stock Prices. The Journal of Finance, 47(2), 733-752. http://dx.doi.org/10.1111/j.1540-6261.1992.tb04407.x

Hite, G., \& Warga, A. (1997). The Effect of Bond-Rating Changes on Bond Price Performance. Financial Analysts Journal, May/June, 35-51. http://dx.doi.org/10.2469/faj.v53.n3.2083

Holthausen, R., \& Leftwich, R. (1986). The Effect of Bond Rating Changes on Common Stock Prices. Journal of Financial Economics, 17, 57-89. http://dx.doi.org/10.1016/0304-405x(86)90006-1

Jorion, P., \& Zhang, G. (2007). Information effects of bond rating changes: The role of the rating prior to the announcement. The Journal of Fixed Income, 16(4), 45-59. http://dx.doi.org/10.3905/jfi.2007.683317

Jorion, P., Liu, Z., \& Shi, C. (2005). Informational effects of regulation FD: Evidence from rating agencies. Journal of Financial Economics, (76), 309-330. http://dx.doi.org/10.1016/j.jfineco.2004.05.001

Jorion, P., Shi, C., \& Zhang, S. (2009). Tightening credit standards: the role of accounting quality. Review of Accounting Studies, 14, 123-160. http://dx.doi.org/10.1007/s11142-007-9054-z

Katz, S. (1974). The price adjustment process of bonds to rating reclassification: A test of bond market efficiency. The Journal of Finance, 29(2), 551-559. http://dx.doi.org/10.1111/j.1540-6261.1974.tb03069.x

MacKinlay, A. C. (1997). Event Studies in Economics and Finance. Journal of Economic Literature, 35(1), 13-39. http://dx.doi.org/10.1016/1062-9769(95)90047-0

Micu, M., Remolona, E., \& Wooldridge, P. (2004). The price impact of rating announcements: Evidence from the credit default swap market. BIS Quarterly Review, June, 55-65. http://dx.doi.org/10.2139/ssrn.911598

Minardi, A. M. A. F. (2008). Probabilidade de inadimplência de empresas brasileiras refletida nas informações $\begin{array}{llll}\text { do mercado } & \text { acionário. } & \text { 311-329. }\end{array}$ http://dx.doi.org/10.11606/d.12.2008.tde-04062008-120550

Moody's Investors Service. (2002). Understanding Moody's Corporate Bond Ratings and Rating Process. May 2002.

Pilar, A., \& Dolores, R. M. (2014). Credit rating agencies and idiosyncratic risk: Is there a linkage? Evidence from the Spanish Market. International Review of Economics and Finance, 33, 152-171. http://dx.doi.org/10.1016/j.iref.2014.05.002

Pinches, G., \& Singleton, J. (1978). The adjustment of stock prices to bond ratingchanges. The Journal of Finance, 33(1), 29-44. http://dx.doi.org/10.2307/2326348

Standard \& Poor's. (2009). Use of credit watch and outlooks. Annual Report. http://dx.doi.org/10.2139/ssrn.1462712

Steiner, M., \& Heinke, V. (2001). Event study concerning international bond price effectsof rating actions. International Journal of Finance \& Economics, 6(2), 139-157. http://dx.doi.org/10.1002/ijfe.148

Wansley, J. W., Glascock, J. L., \& Clauretie, T. M. (1992). Institutional Bond Pricing and Information Arrival: The Case of Bond Rating Changes. Journal of Business Finance \& Accounting, 19(5), 733-750. http://dx.doi.org/10.1111/j.1468-5957.1992.tb00654.x 
Weinstein, M. (1977). The Effect of a Rating Change Announcement on Bond Price. Journal of Financial Economics, 5, 329-350. http://dx.doi.org/10.1016/0304-405x(77)90042-3

\section{Copyrights}

Copyright for this article is retained by the author(s), with first publication rights granted to the journal.

This is an open-access article distributed under the terms and conditions of the Creative Commons Attribution license (http://creativecommons.org/licenses/by/3.0/). 